\title{
名勝としての「展望地点」の保護に関する研究
}

\section{A Study on the Protection of "Panoramic Views" as Places of Scenic Beauty}

上村さつき* 黒田 乃生** 羽生 冬佳**

Satuski KAMIMURA Nobu KURODA Fufuka HANYU

\begin{abstract}
The aim of this study is to consider the ideal methods of protection for the Panoramic Views, which are designated Cultural Properties, through the analysis of the following points: 1) The present status of protection given, from the view of the facilities' management. 2) Other similar protection systems. 3) Case studies detailing the Panoramic Views` management and changes, before and after designation as Cultural Properties, to clarify the effectiveness of the protection system. From this, it was gathered that the Panoramic Views have been managed and maintained by additional protection systems and departments; it has not been solely under the control of Cultural Properties. Considering the findings above, the premise that Cultural Properties were providing the maintenance and management to protect these panoramic views, in terms of the protection under Cultural Properties law, has been found to be unproved. For the protection of the Panoramic Views to be effectively maintained, it is important to continue providing opportunities for local people and tourists to view these locations. However, designation as official Cultural Properties was helpful to create and realize an initial opportunity for protection. From this point onwards, in order to sustain the viewing opportunities, it is a requisite to protect the Panoramic Views for flexible use in conjunction with other protection systems.
\end{abstract}

Keywords: panoramic views, places of scenic beauty, cultural properties, protection system キーワード：展望地点, 名勝, 文化財, 保護制度

\section{1.はじめに}

\section{(1) 背景と目的}

近年, 景観法の施行や文化的景観の文化財保護法への導入など 景観保護に関する気運が高まっており，どのように景観を保護し ていくか今後ますます問われることになると予想される。景観は, 眺める場所（=展望地点）があって初めて成立するものであるた め, 展望地点は景観を語る上で欠かす事のできない要素であると いうことができる。

文化財保護法では, この展望地点が保護対象として位置づけら れている。同法における名勝の指定基準は 11 項目あり（表一 1 ）, その 11 番目が展望地点となっている。展望地点という指定基準 によって名勝の指定がはじまってから約 90 年が経ち, 文化財保 護の視点から展望地点の保護と問題点と有効性を検証することは 今後の景観保護のためにも必要であると考えられる。

一般的な展望地点を対象にした研究として, 鄭らは視点場と視 対象の可視不可視の関係に着目している ${ }^{1)}$ 。また, 石田尾らは事 例研究を通して, 名勝における眺望点の確保や対象地の阻害要因 規制の必要性を述へてている ${ }^{2)}$ 。さらに, 名勝指定された「展望地 点」を対象とした研究には, 史蹟名勝天然紀念物保存法に関わる 研究 ${ }^{3)}$ や名勝の現状についての数量的分析 ${ }^{4)}$ があるが，これらは

\section{表 -1 特別史跡名勝天然記念物及び史跡名勝天然記念物指定基準}

\begin{tabular}{|c||l|}
\hline 一 & 公園、庭園 \\
\hline 二 & 橋梁、築堤 \\
\hline 三 & 花樹、花草、紅葉、緑樹などの叢生する場所 \\
\hline 四 & 鳥獣、魚虫などの生息する場所 \\
\hline 五 & 岩石、洞穴 \\
\hline 六 & 溪谷、瀑布、渓流、深淵 \\
\hline 七 & 湖沼、湿原、浮島、湧泉 \\
\hline$八$ & 砂丘、砂嘴、海浜、島嶼 \\
\hline 九 & 火山、温泉 \\
\hline+ & 山岳、丘陵、高原、平原、河川 \\
\hline 十一 & 展望地点 \\
\hline
\end{tabular}

名勝全体を対象とした歴史研究または現状把握であり，「展望地 点」について俯瞰的にその有効性を論じた研究はない。

そこで, 本研究では展望地点として名勝に指定されている文化 財（以下「展望地点」）を対象に，施設整備と管理という視点か ら保護の現状を検討する。同時に「展望地点」の保護がその他の 制度で担保されている場合も想定されるため, 文化財以外の制度 についても把握する。次に, 現状を踏まえて保護制度の有効性に ついて検討するために, 3 件の事例について指定経緯, 指定前後 の変化と管理の詳細な現状を明らかした。以上の結果をから, 名 勝としての「展望地点」における文化財保護の今後のあり方につ いて考察する事を本研究の目的とする。

\section{(2) 研究の方法}

「展望地点」の保護の現状は，アンケート調查から把握を行っ た。「展望地点」として指定された名勝が所在する 21 市町村 (24 件の名勝) のうち, 回答があったのは琴平町（象頭山）を除く, 20 市町村（23 件の名勝）であった。さらに，指定基準が「展望 地点」のみで指定された 7 件の名勝のうち, 指定当時の資料が多 く残り, 指定後の変化の状況について把握する事が可能な「下津 井熟羽山」,「天都山」,「雙ヶ岡」の 3 箇所について, 文献調査, 地形図, 現地調查および文化財担当者へのヒアリングによって, 指定の経緯，指定後の景観の変化を把握した。

\section{2.「展望地点」の概要}

現在, 国指定の名勝は 354 件あるが, そのうち展望地点を含む 複数の指定基準で指定されたものが 24 件, 展望地点単独の指定 は 7 件である（表 -2 )。

史蹟名勝天然紀念物保存法の成立をめぐって, 大正 8 (1919) 年には作成段階にあった「史蹟名勝天然紀念物保存法」保存要目・ 名勝の部草案においては, 26 ある項目の第一項目に「風景 7 眺 メ得ル地點」があげられていたが，大正 9 （1920）年に決定され た保存要目では, 名勝の部の項目は 11 に整理され，展望地点は

\footnotetext{
${ }^{*}$ 十一房印刷工業株式会社 ${ }^{* *}$ 筑波大学大学院人間総合科学研究科世界遺産専攻
} 
最後の 11 番目になり, 表現は「著名ナル風景 7 眺入得ル特殊ノ 地點」へと変化したことは知られている ${ }^{5)}$ 。また, 大正期から昭 和初期にかけて, 国立公園の指定に関連して田村剛と脇水鉄五郎 が展望地点について言及している ${ }^{6)}$ 。

昭和初期から指定が始まった展望地点は, 昭和 34（1959）年 の「日本平」の指定を最後に約 40 年に渡って指定が行われない 時期があった。その後, 平成 9 （1997）年の「川平湾及び於茂登 岳」を皮切りに, 文化的景観のテストケースなどとして指定が再 開された ${ }^{7)}$ ○の他に「展望地点」として指定されたものを概観 すると, 松島や天橋立のように昔から景勝地とされていたところ, 下津井鷲羽山（岡山県）をはじめとするアルピニズムなどの近代 的風景観によって新たに発見された風景を眺め得る「展望地点」 が多く指定されていることがわかる。

\section{表 -2 「展望地点」指定物件}

\begin{tabular}{|c|c|c|c|}
\hline 指定名称 & 所在地 & 指定年月日 & 指定基準 \\
\hline 天橋立 & 京都狩宫津市 & $1918 / 03 / 07$ & 名 $3 / 8 / 11$ \\
\hline 松島 & 宮城県塩釜市 & $1919 / 03 / 06$ & 名 $8 / 11$ \\
\hline 下津井鷲羽山 & 岡山県倉敷市 & $1926 / 11 / 18$ & 名 11 \\
\hline 鳴門 & 德島県鳴門市 & $1927 / 02 / 19$ & 名 $8 / 11$ \\
\hline 鳳来寺山 & 愛知県南設楽郡 & $1931 / 04 / 31$ & 名 $3 / 4 / 5 / 10 / 11$ 植 $2 / 9$ 地 $1 / 7$ \\
\hline 奈曽の白瀑谷 & 秋田県由利郡 & $1928 / 03 / 24$ & 名 $6 / 11$ \\
\hline 霊山 & 福島県伊達郡 & $1930 / 04 / 30$ & 史 2 名 $10 / 11$ \\
\hline 六郎次山 & 熊本県天草郡 & $1931 / 06 / 06$ & 名 11 \\
\hline 千厳山及び高舞登山 & 熊本県天草郡 & $1931 / 06 / 06$ & 名 11/5 \\
\hline 竜ヶ岳 & 熊本県天草郡 & $1932 / 09 / 02$ & 名 11 \\
\hline 天都山 & 北海道網走市 & $1934 / 12 / 13$ & 名 11 \\
\hline 金峰山 & 山形県鶴岡市 & $1937 / 04 / 22$ & 名 $11 / 10$ \\
\hline 雙ヶ岡 & 京都市右京区 & $1937 / 11 / 12$ & 名 11 \\
\hline 白石島 & 岡山県笠岡市 & $1939 / 02 / 18$ & 名 $8 / 11$ \\
\hline 応神山 & 岡山県笠岡市 & $1939 / 08 / 26$ & 名 11 \\
\hline 八幡山 & 愛媛県今治市 & $1940 / 11 / 06$ & 名 11 \\
\hline 高島 & 岡山県笠岡市 & $1940 / 11 / 06$ & 名 $8 / 11$ \\
\hline 象頭山 & 香川県仲多度郡 & $1947 / 06 / 08$ & 名 $11 / 3$ \\
\hline 日本平 & 静岡県清水市 & $1955 / 06 / 06$ & 名 $11 / 10$ \\
\hline 川平湾及び於茂登岳 & 沖縄県石垣市 & $1993 / 09 / 10$ & 名 $8 / 10 / 11$ \\
\hline 姨捨 & 長野県更埴市 & $1995 / 05 / 09$ & 名 $3 / 4 / 11$ \\
\hline 白米の千枚田 & 石川県輪島市 & $1997 / 01 / 28$ & 名 $3 / 4 / 11$ \\
\hline イーハトーブの風景地 & 岩手県花巻市他 & $2001 / 03 / 01$ & 名 $6 / 10 / 11$ \\
\hline 大和三山 & 奈良県橿原市 & $2001 / 07 / 13$ & 名 $3 / 10 / 11$ \\
\hline
\end{tabular}

\section{3.「展望地点」の指定と管理現状}

本章では, アンケート調査の結果から「展望地点」の保護の現 状について明らかにする。

\section{(1) 展望の対象}

アンケートの回答は，筆者が事前に名勝指定理由を分析して抽 出した「島並」「都市や街」「山」「海」「その他」の五項目からの 選択式とした（表－3）。展望地点から見える景色として一番多 いのが「山」である。19 件で「山」の回答があり, 次に多いの が「海」で 16 件であった。回答数の多かったのがこの二つで,

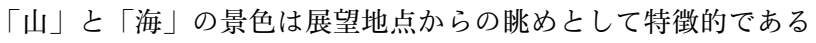
といえる。また，「島並み」が見えるのは 9 件あった。さらに, 「都市や街」は 12 件と展望地点指定数の半数にのぼることが明ら かになった。

\section{（2）施設の整備}

(i) 展望施設

18 件において何らかの展望施設がある（表－4）。これらは, 名勝に指定された場所の保護というょりはむしろ, 利用を念頭に 入れて展望地点が整備されていることが判る。

展望地点にある施設は「広場」が最も多く 13 件。その次が
表－3 展望地点から見える景色

\begin{tabular}{|l|c|c|}
\hline \multicolumn{1}{|c|}{ 展望地点から見える景色 } & 件数 & $\%$ \\
\hline \hline$山$ & 19 & 83 \\
\hline 海 & 16 & 70 \\
\hline 都市や街 & 12 & 52 \\
\hline 島並み & 9 & 39 \\
\hline その他 (滝・湖・川・高原等) & 5 & 22 \\
\hline \multicolumn{2}{|c|}{ (複数回答 $\mathrm{n}=23$ ) } \\
\hline
\end{tabular}

表 -4 展望施設の有無

\begin{tabular}{|l|c|c|}
\hline \multicolumn{1}{|c|}{ 展望施設の有無 } & 件数 & \% \\
\hline \hline 展望施設がある & 18 & 78 \\
\hline 展望施設がない & 5 & 22 \\
\hline 合計 & 23 & 100 \\
\hline
\end{tabular}

「屋根付き休覟所」「ベンチ」で,

\section{表 -5 展望施設の形態}

\begin{tabular}{|l|c|c|}
\hline 展望施設の形態 & 件数 & $\%$ \\
\hline \hline 広場 & 13 & 57 \\
\hline 屋根付き休敗所 & 11 & 48 \\
\hline バンチ & 11 & 48 \\
\hline 展望のための建物 & 8 & 35 \\
\hline 望遠鏡 & 3 & 13 \\
\hline
\end{tabular}
共に 11 件ある。さらに,「展望のための建物(展望台等)」は 8 件 が，「望遠鏡」は 3 件がこれを有している（表－5）。

(ii ) 展望施設以外の施設

展望施設以外の形態として最も多いのは「道」であり 18 件で 整備されている。また，レストランや土産物屋などは 4 件ある。 他には,「トイレ」「棚田オーナーの休鄎所」「駐車場」など利用 者のための施設が整備されている物件は合わせて 7 件ある（表一 6 )。それ以外の施設としては,「応神山」の「鉄塔」や，「日本 平」の「テレビ塔」などが挙げられる。名勝に限らず, 記念物に ついては現状保存が原則であり ${ }^{8)}$, 積極的な復旧, 修復, 整備と いった施策はなされないのが通常であるが，指定範囲で施設整備 が行なわれている展望地点は, 名勝, さらには記念物の中でも特 異な存在であるという事が出来る。

\begin{tabular}{|c|c|c|}
\hline 展望施設の形態 & 件数 & $\%$ \\
\hline 登山道・遊歩道等 & 18 & 78 \\
\hline トイレ & 5 & 22 \\
\hline 観光施設（レストラン・土産物屋等） & 4 & 17 \\
\hline 電波塔 & 2 & 9 \\
\hline ロープウェイ駅 & 1 & 4 \\
\hline 棚田オーナーの休憩所 & 1 & 4 \\
\hline 駐車場 & 1 & 4 \\
\hline
\end{tabular}

( 3 ）「名勝」以外の保護制度の有無

「展望地点」の文化財以外の保護制度は表－ 7 のとおりである。 24 件のうち 21 件, 88\%が自然公園に指定されている。このうち, 国立公園は 12 件である。瀬戸内海国立公園が最も多く 12 件中 7 件, 雲仙天草国立公園が 3 件, 西表国立公園と十和田八幡平国立 公園が 1 件ずつとなっている。国定公園は 5 件，都道府県立自然 公園は 4 件ある。

自然公園がないのは「雙ヶ岡」,「大和三山」,「姨捨」の 3 件で ある。そのうち京都市の「雙ヶ岡」と橿原市「大和三山」が古都 における歴史的風土の保存に関する特別措置法（「古都保存法」） によって歴史的風土特別保存地区に指定されている。その他, 都 市計画に関連するものでは風致地区が 3 件, 都市公園が 2 件ある。

「展望地点」はそのほとんどが何らかのかたちで名勝以外の保 護制度が担保されていることが明らかになった。

表 -7 文化財以外の保護制度

\begin{tabular}{|l|l|c|c|}
\hline \multicolumn{1}{|c|}{ 法 律 } & \multicolumn{1}{|c|}{ 指 定 } & 件数 & $\%$ \\
\hline \hline 自然公園法 & 自然公園 & 21 & 88 \\
\hline 古都保存法 & 歴史的風土特別保存地区 & 2 & 8 \\
\hline \multirow{2}{*}{ 都市計画法 } & 風致地区 & 3 & 13 \\
\cline { 2 - 5 } & 都市公園 & 2 & 8 \\
\hline
\end{tabular}

（4）管理体制

(i ) 管理主体と管理内容 
展望地点を実際に管理しているのは地方自治体の観光課, また は地元有志等の地域住民および宗教法人によるものであることが 明らかになった。具体的な管理内容としては, 来訪者の為の施設 整備や景観阻害樹木の伐採等が観光課によって, 美化・清掃が地 元有志等によって行なわれている。結果として, 展望地点に指定 されている場所で文化財担当部署によって保護・管理が行なわれ ているところは少ない，ということが明らかになった。13 件に おいては民間の管理団体が存在しているが，これらは物件を有す る宗教団体や，町内会などの地元有志に拠るものである（表－8）。

表 -8 管理主体と管理内容

\begin{tabular}{|c|c|c|c|c|c|c|c|}
\hline \multirow{2}{*}{\multicolumn{2}{|c|}{ 管理主体 管理内容 }} & \multicolumn{2}{|c|}{ 美化·清掃 } & \multicolumn{2}{|c|}{$\begin{array}{c}\text { 景観阻害樹木の } \\
\text { 伐採 }\end{array}$} & \multicolumn{2}{|c|}{$\begin{array}{l}\text { 来訪者の為の } \\
\text { 施設整備 }\end{array}$} \\
\hline & & 件数 & $\%$ & 件数 & $\%$ & 件数 & $\%$ \\
\hline \multirow{3}{*}{ 市 町 村 } & $\begin{array}{l}\text { 文化財課 } \\
\text { 社会教育課 }\end{array}$ & 1 & 4 & 3 & 13 & 1 & 4 \\
\hline & $\begin{array}{l}\text { 観光課 } \\
\text { 観光振興課 }\end{array}$ & 2 & 9 & 3 & 13 & 6 & 26 \\
\hline & その他 & 2 & 9 & 3 & 13 & 5 & 22 \\
\hline \multicolumn{2}{|c|}{ 京都市文化観光資源保護財団 } & 1 & 4 & 1 & 4 & 1 & 4 \\
\hline \multicolumn{2}{|c|}{ 地域住民·宗教法人等 } & 8 & 35 & 2 & 9 & 3 & 13 \\
\hline
\end{tabular}

(ii) 保存管理計画

名勝の保存管理計画を策定している自治体の数は, アンケート に回答のあった 23 件中 9 件である。このうち近年指定を受けた 物件は 5 件中 4 件が策定，または現在策定中であるが，昭和 34 年までに指定された名勝に限ると保存管理計画を策定しているの は 18 件 5 件と少ない。

\section{4. 展望地点の指定経緯と現況}

本章では, 下津井鷲羽山, 天都山, 雙ヶ岡を事例として, (1)指 定の経緯 (文献研究), (2)周辺環境の変化 $(1 / 25000$ ・1/50000の 地形図の分析等), (3)展望地点の現状(現地調査・文化財担当者へ のヒアリング), から「展望地点」の保護の意義とありかたにつ いて検討する。

\section{(1) 下津井鷲羽山}

(i) 指定の経緯

熟羽山は近代に入るまで登る人も少ない山であったが，昭和 2 （1927）年に大阪毎日新聞社・東京毎日新聞社主催で行なわれた 「日本新八景」の選出において, 熟羽山周辺の下津井海岸が「百 景地」の一つに選ばれ知名度が高まり, 観光地として注目を集め るようになった ${ }^{9)}$ 。しかし, 観光客目当ての露店が出る程に賑わ い, それにより熟羽山の風致が破壊されていることから, 昭和 5 （1930）年 6 月, 下津井町長 - 中西幸太郎加ら名勝指定による保 護が申請されている ${ }^{10)}$ 。また, 昭和 4 年から 5 年にかけて理学博

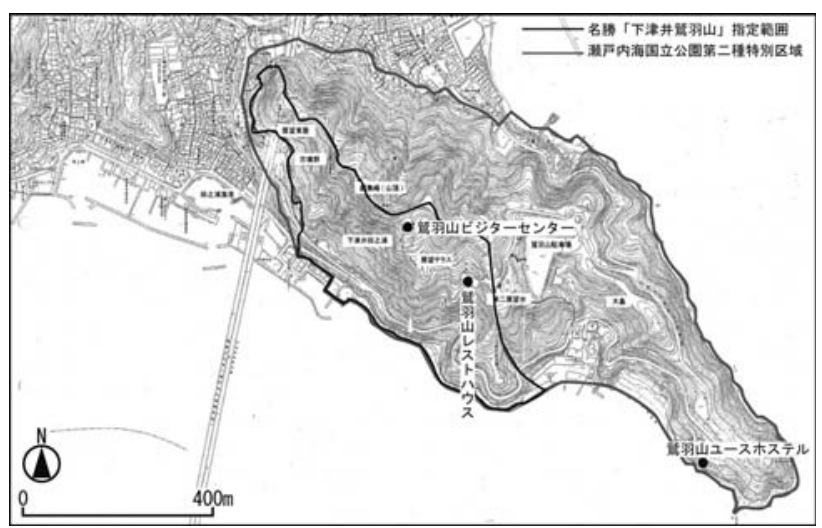

図-1 名勝「下津井鷲羽山」・瀬戸内海国立公園指定範囲 （倉敷市教育委員会文化財課所蔵「国指定史跡名勝天然記念物指定台帳」 『名勝「下津井鷲羽山」指定範囲』を元に作成)
士・脇水鉄五郎と林学博士・田村剛らにより史蹟名勝天然紀念物 調査と国立公園候補地視察が行われ，この二人によって熟羽山の 知名度は上がり, 瀬戸内海の展望地点として認知され, 昭和 5 （1930）年 11月「下津井熟羽山」として国の名勝に指定された ${ }^{11}$ 。 さらに，昭和 9 （1934）年には，瀬戸内海国立公園としても指定 を受けている ${ }^{12)}$ 。

(ii）展望地点の変化

熟羽山の展望地点はその山頂, 山頂からやや標高の低い第二展 望台, 山を周回する登山道等がある。昭和 5 （1930）年には, そ の登山道が改修され ${ }^{13}$, 翌年には下津井軽便鉄道の熟羽山駅が新 設されている。また，昭和 7 （1932）年，頂上までの道路が建設 されるなど，徐々に整備が進んだ ${ }^{14)}$ 。戦時中，その整備は一時中 断するが, 戦後, 下津井鉄道の電化, 岡山・熟羽山間のバスの運 行が再開されている。その後も, 昭和 35 (1960）年の熟羽山ユー スホステル, 昭和 38 （1963）年の熟羽山レストハウス，昭和 60 年のビジターセンターの建設などが行われた。

(iii）展望対象の変化

熟羽山からは瀬戸内海の多島海景を望むことができる。しかし, その風景は昭和 63 （1988）年に開通した瀬戸大橋の架橋によっ て変化した。橋は, 経済性の高さを狙い, 鷲羽山からの多島海景 を縫うように名勝指定範囲内の西端から四国まで架けられた。瀬 戸内海の経済の効率化を目的とした架橋であったが，「瀬戸内海 の多島美の破壊」など否定的な意見もあった ${ }^{15)}$ 。

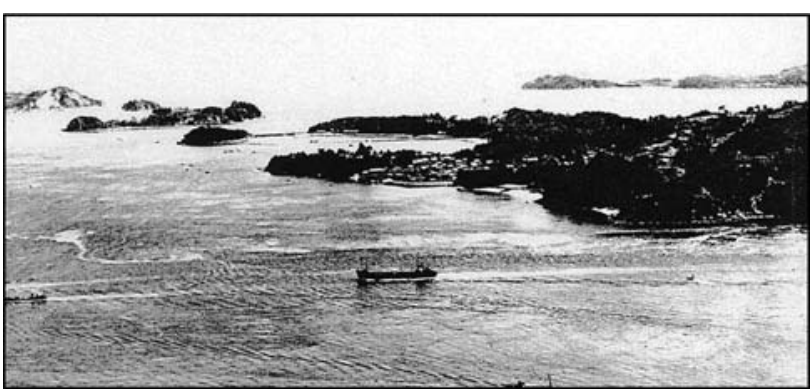

\section{図-2 䉆羽山より塩飽諸島の景（昭和 34 年撮影 倉敷市歴史資料整備室提供）}

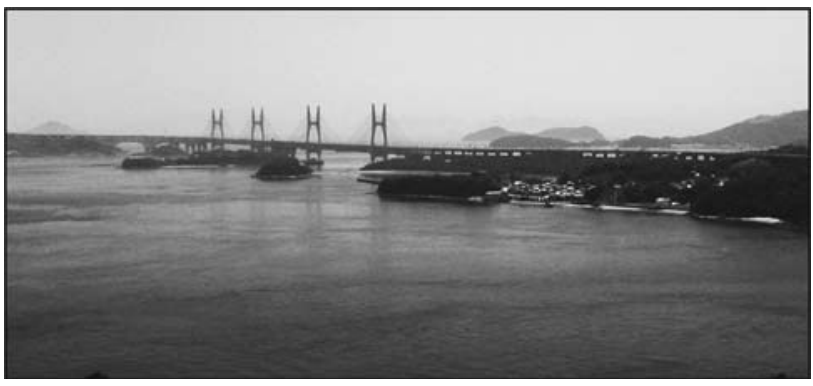

図-3＼cjkstart鷲羽山より塩飽諸島の景(平成 19 年 7 月撮影)
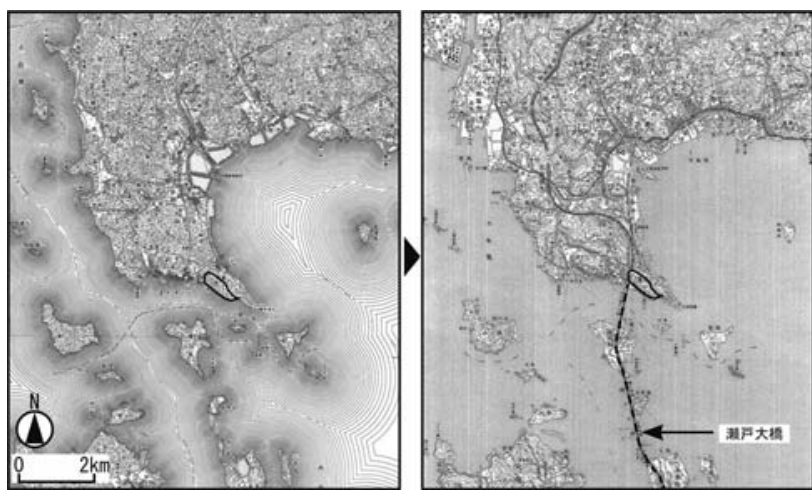

図-4 鷲羽山周辺の变化 昭和 6 年 (左) と昭和 63 年 (右) $\square$ : 名勝指定範囲 (国土地理院発行地形図 $(1 / 25000$ 「野」) より作成) 


\section{（iv）保護管理の現状}

熟羽山の名勝指定範囲の管理主体は, 倉敷市教育委員会生涯学 習部文化財保護課である ${ }^{16)}$ が，具体的な管理は行なわれていない 事が担当者へのヒアリングにより明らかになった ${ }^{17)}$ 。保存管理計 画について岡山県から作成の要請はあるものの, 準備段階から前 進していない。実際の管理は, 国立公園としての熟羽山の管理主 体である環境省中国四国地方環境事務所により要請を受けた岡山 県・倉敷市の土木部（景観阻害樹木の剪定等）や，倉敷市の観光 振興課（指定範囲内の施設管理）によって行なわれている。

(2) 天都山

(i ) 指定の経緯

天都山は大正末期までは名も無い山であったが，大正 14 （1925）年，その地を訪れた網走支庁長により「天の都にいる心

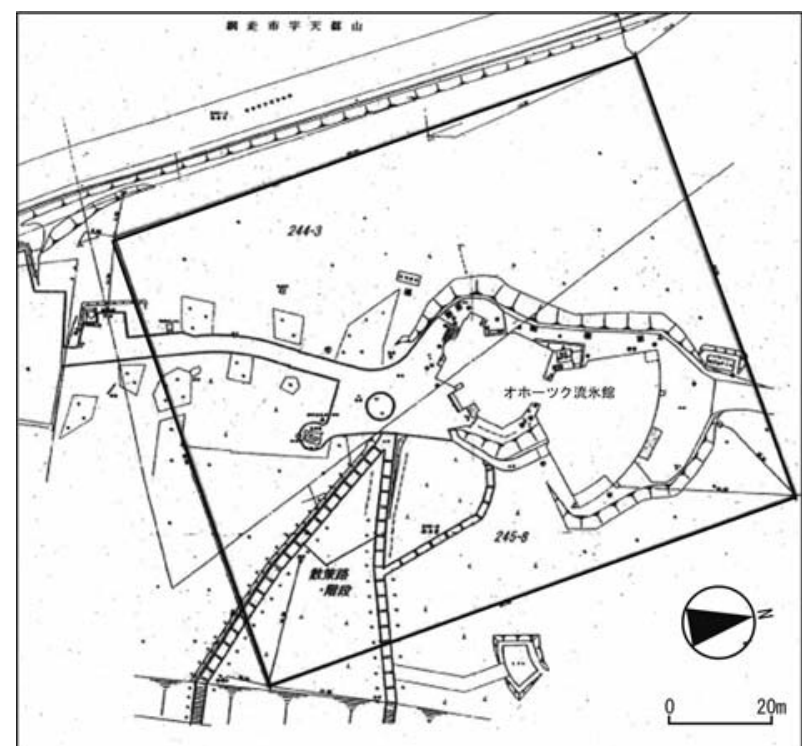

図- 5 名勝「天都山」指定範囲 (網走市立郷土博物館所蔵「指定台帳個表」 『史跡指定範囲詳細図 1/800』を元に作成)

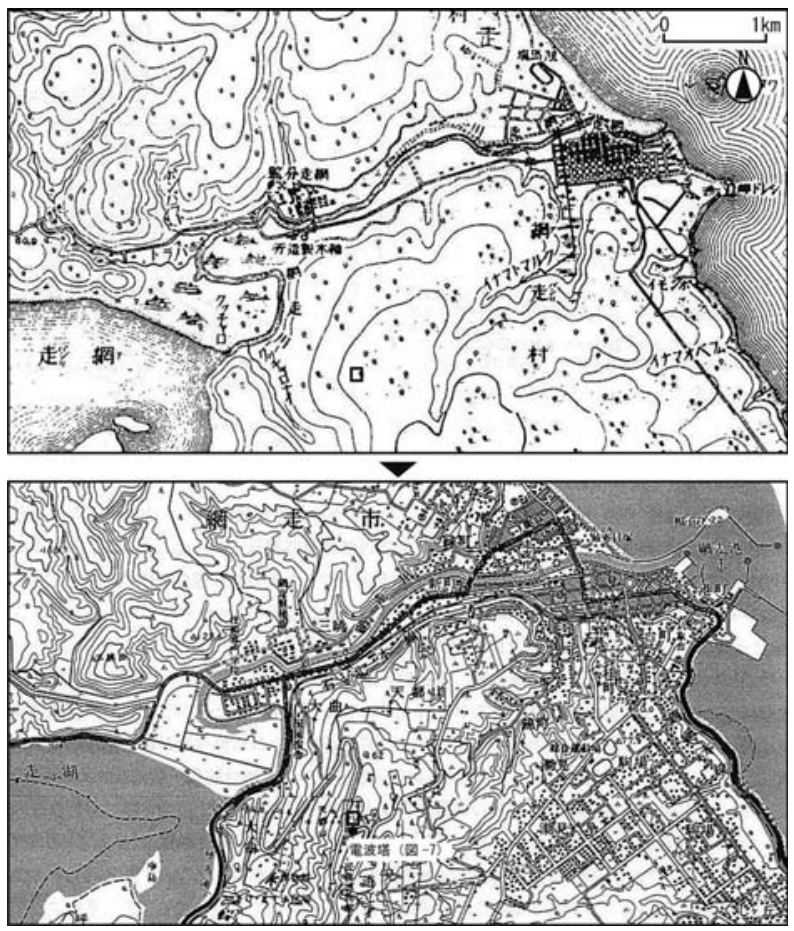

図-6 天都山周辺の変化（明治 30 年 (上) 平成 18 年 $(下) ） \square:$ 名勝指定範四 (国土地理院 旧版地図（1/5000「網走」「網走湖」「常呂」「濤沸湖」）を元に作成）

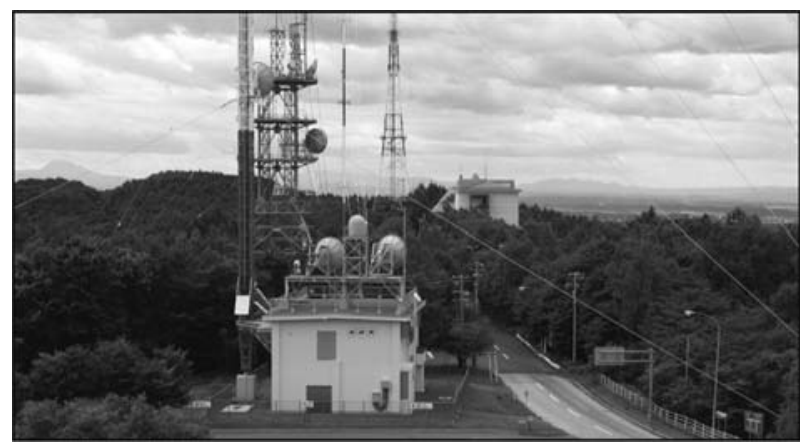

図-7 天都山から電波塔（平成 19 年 7 月著者撮影）

地がする」と天都山と名付けられたことにより, 徐々に知名度を 獲得した。命名を機に網走町では天都山道路を開削し, 町長らが 名勝の指定を働きかけている ${ }^{18)}$ 。さらに, 昭和（1394） 9 年に発 行された『北海道景勝地概要 19』』では, 54 ある景勝地の 1 つと して取り上げられ，「網走町民其の他の遊覧社四時絶へず」とあ り, 数年前までは認知されていなかった天都山が集客力のある観 光地へと変化したことがわかる。景勝地としての認知が高まり, 昭和 13 （1938）年に名勝の指定を受けた ${ }^{20)}$ 。さらに，昭和 32 （1957）年には網走国定公園としても指定されている ${ }^{21}$ 。

(ii ）展望地点の変化

天都山の展望地点は，その山頂である。名勝の指定を受けてか ら, 天都山は北海道東部の観光地に名を連ねるようになり, 網走 市によって整備が始まった。昭和 26（1951）年には展望台を設 置, 翌年には展望台へ至る遊歩道を設置, さらに昭和 28 (1953) 年には山頂に休䕀所を建設。昭和 32 (1957) 年には天都山道路 開通にともないバス路線を開設した。昭和 50 年代後半からは天 都山におてい観光施設の建設が始まった。現在では, 名勝指定範 囲とその周辺には観光拠点が集まっている。網走市の中でも，年 間利用者数の上位 5 位までに含まれる施設の内, 3 つ（網走監獄, オホーツク流水館，北方民俗博物館）の施設が天都山にある ${ }^{22)}$ 。 観光施設以外にも，昭和 36（1961）年，NHK の電波塔が名勝指 定範囲から $100 \mathrm{~m}$ の場所に建設されたのを皮切りに，天都山は現 在では, 道東エリアの電波送信所（テレビ・ラジオ各局の送信所） となり，電波塔が立ち並ぶ山になった。

(iii）展望対象の変化

天都山からの景色の特徵は遮るもののないパノラマ景である。 その山頂からはオホーツク海, 大雪・阿寒・知床国立公園や網走 国定公園を見渡す事が出来る。それらに変わりはないが，市街地 の伸張や，指定範囲周辺に電波塔（図一 7 ）方建設された事によ り，天都山から望む景観は変化している。

（iv）保護管理の現状

名勝の管理団体として指定を受ける網走市は現在, 天都山の名 勝としての管理は行なっておらず，また保存管理計画も作成して いない ${ }^{23)}$ 。実際の管理を行なっているのは, 網走国定公園の管理 者である北海道庁網走支庁環境生活課主査（園地内の施設の整備 改良・支障木の伐採を行なう）や，名勝指定範囲内にある「オホー ツク流水館」の管理団体である網走観光振興公社（美化・清掃, 芝生や樹木の管理を行なう) である。

\section{(3) 雙ヶ岡}

\section{(i ) 指定の経緯}

雙ヶ岡の名勝指定までの経緯については不明な点が多いが，大 正 4 （1915）年発行の『新撰京都名勝誌』 ${ }^{24)}$ や, 昭和 3 (1928) 年発行の『京都名勝誌』 ${ }^{25)}$ に, 雙ヶ岡が古来より著名人ゆかり の地であったこと, 詩歌に詠まれてきたこと, またその山容につ いて記され，文人墨客ゆかりの名所として認識されていたと推測 できる。名勝指定以前の文化庁による調査の報告書 ${ }^{26)}$ でも, 雙 


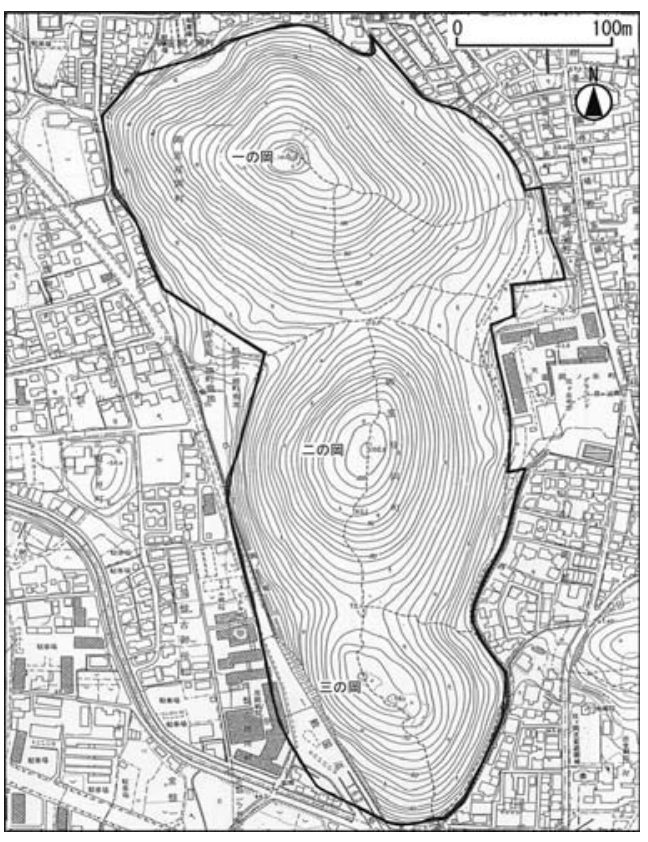

図-8 名勝「雙ヶ岡」指定範囲図 $\square$ : 名勝指定範囲 点線部：周回路（京都市文化財課提供・「名勝指定範囲図」を元に作成）

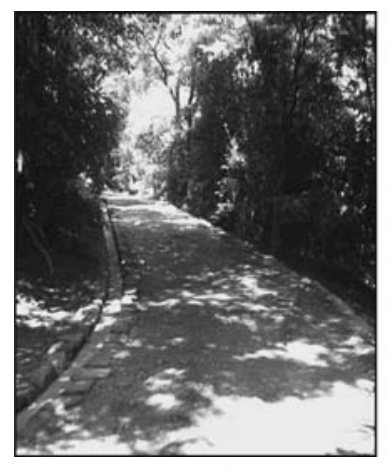

図-9 周回路の写真

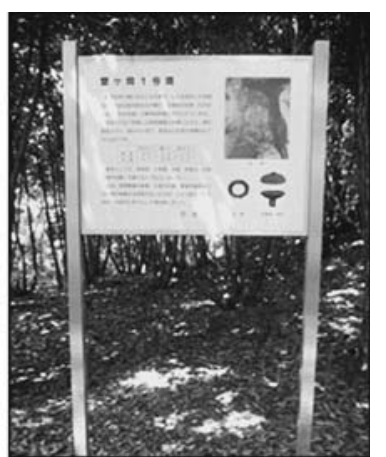

図-10 名勝内遺跡説明版の写真
(平成 19 年 7 月撮影)

ヶ岡からの展望の写真は全 16 枚中 5 枚であり, 展望についての 記述はない。調書のほとんどが, 雙ヶ岡が著名人ゆかりの地であ ること, 近隣の社寺などとの関連性等についてであり, 展望より も雙ヶ岡自体の歴史的意義が重視されているように考えられる。 昭和 16 (1941）年に雙ヶ岡は, 名勝に指定される めて「眺望」という言葉が記載されている ${ }^{28)}$ 。

(ii）展望地点の変化

雙ヶ岡は一の岡・二の岡・三の岡の三つの岡からなり, 一の岡・ 二の岡から京都市の名所を望む事が出来る。昭和 54 (1979) 年 からは, 全域で環境整備が進められている。この整備は雙ヶ岡が 内包する歴史的, 自然的イメージを利用者が体験する契機となる 事を狙いとして ${ }^{29}$, 周回路 (図-9) や展望広場の整備, さらに 名勝内の遺跡説明板 $($ 図 -10$)$, 道標や注意板, ベンチの設置も 行なわれた。

\section{(iii）展望対象の変化}

雙ヶ岡からは洛東の諸山（比㕡山・鞍馬山・高雄山）や，嵐山・ 嵯峨野, さらに洛中の市街より四条街道までの一帯, 仁和寺等を 眺める事が出来る。名勝指定された当時は, 一の岡周辺及び東側 を中心に僅かに宅地が形成するだけで, 水田や茶畑・竹林など大 部分が農業的土地利用に供されていた。しかし, 昭和 40 年代に は雙ヶ岡周辺地域で都市化が急激に進行し, 宅地開発が進んで農 地に次々と住宅が建設された。市街地の伸張（図-11）によって, 雙ヶ岡からの景観は変化している。
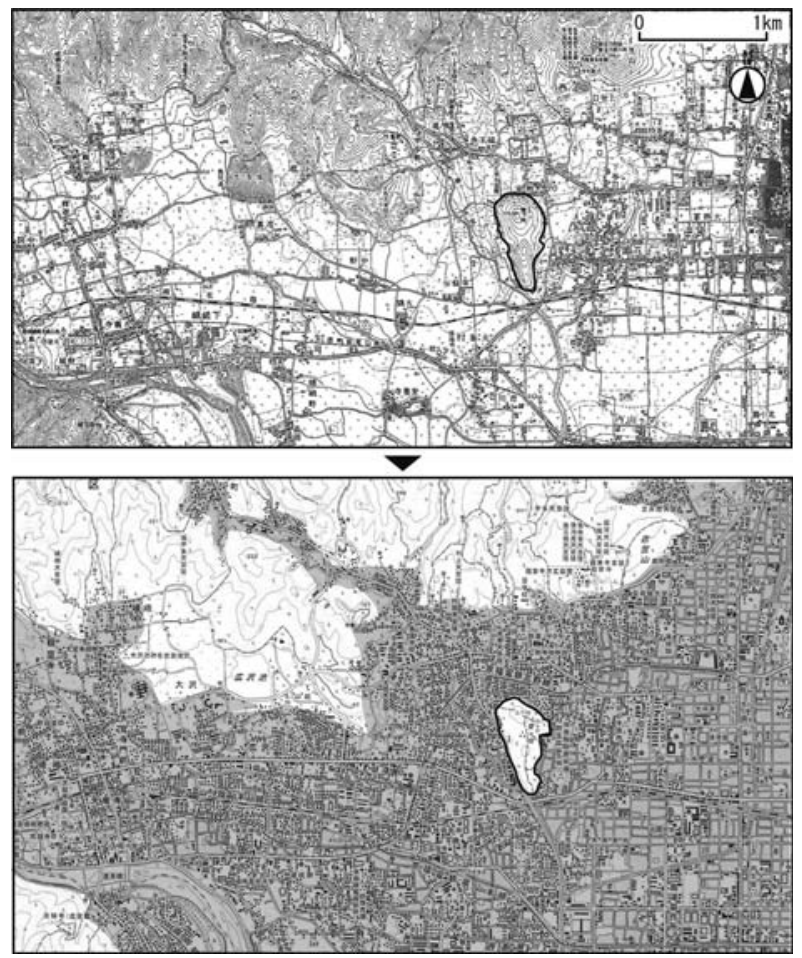

図-11 雙ヶ岡周辺の変化（大正 14 年 (上) 平成 18 年 (下)) $\quad \square$ : 名勝指定範囲 口: 市街地部分（国土地理院（1/25000「京都西北部」）を元に作図）

（iv）保護管理の現状

雙ヶ岡の管理は, 京都市文化市民局文化芸術都市推進室文化財 保護課保護第一係が主体となって行なわれている。しかし，一の 岡の所有が現在に至っても仁和寺にある事等を理由に, 保存管理 計画は作成されていない。

実際の管理は, 財団法人京都市文化観光資源保護財団（以降 「財団」とする）が京都市から受託して行なっている。この財団 は，財界・文化人など各界有志の賛同を得て，京都市の出捐金に より昭和 44 (1971) 年に設立された公益法人である。京都市に は多数の文化財が集中しており, 保護は行政の補助が及ばないも のが数多く存在している。これらの文化財を保護するために寄せ られた寄付金等を基金として京都市の文化観光資源の保護・活用 等を行なう団体であり, 雙ヶ岡においても赤松の植林事業や，樹 木の剪定等の環境整備, マツクイムシの駆除事業, 看板の設置等 の管理活動を行なっている。

\section{(4) 小結}

指定とその後の経緯について，3 件の状況はそれぞれ異なるが, ここから「展望地点」が名勝として指定される意味を見いだす事 が出来る。「下津井熟羽山」は当時, 展望台として有名となり観 光客が集まり始めた事によって風致が乱れつつ合った状況を, 名 勝に指定することで食い止めるために申請が行なわれた。「天都 山」の指定は, 名も無い山であった地が名勝に指定された事で知 名度を高め, 結果として観光地としての整備に繋がった。「雙ヶ 岡」は, 京都に数ある名所の一つとして指定されたが, 雙ヶ岡の 一部を所有する仁和寺が民間に売却しようとした際に, 名勝であっ た為に民有地化・開発を免れている。

周辺地域の変化については「下津井熟羽山」には瀬戸大橋が, 「天都山」には電波塔が建設され，「雙ヶ岡」は周囲全てが宅地開 発され，3 箇所全てにおいて展望地点から望む景観が変化してい る事が明らかになった。「展望地点」は保護の対象が展望の場所 だけであるというその性質上, 展望対象の変化について考慮され ていない。その為, 展望対象となる景観は一部他の法制度によっ て保護されている部分を除いて変化している。 


\section{表 $-9 \quad 3$ 件の展望地点の保護管理}

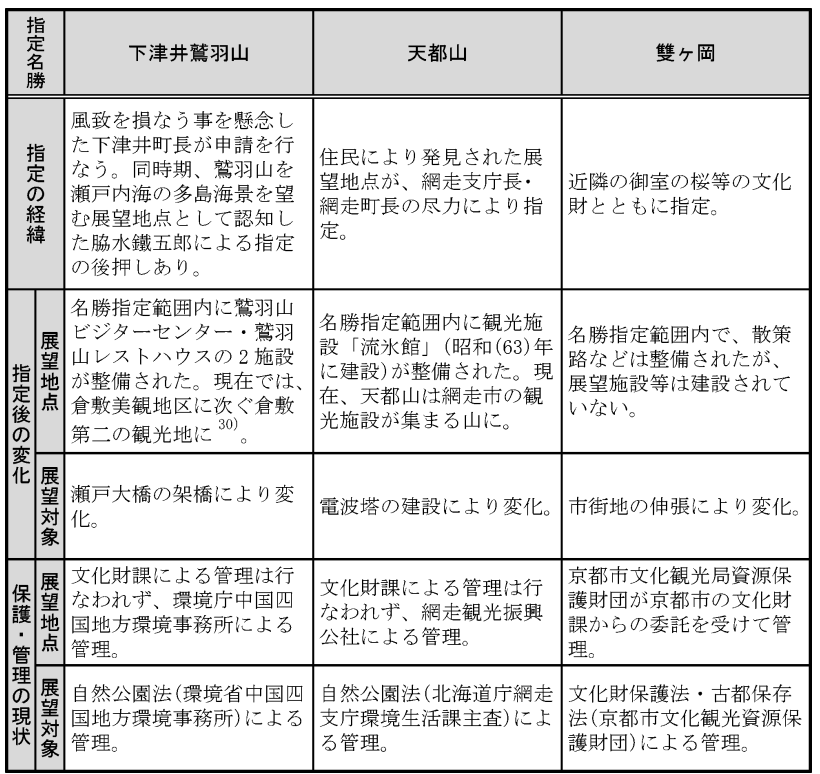

さらに，本章で取り上げた指定物件の担当者へのヒアリングか らは，「雙ヶ岡」を除いて名勝としての管理が行なわれていない, ということが確認された。しかし，「下津井熟羽山」「天都山」 「雙ヶ岡」それぞれにおいて展望施設の整備が行なわれ，「展望」 という行為は確実に発展し, 継承されている事が現地調査から明 らかになった。

\section{5. 結論}

景観を眺める場所である「展望地点」を大正期に保護対象に取 り込んだという事実は, 文化財保護の歴史の中で重要であると考 えられる。調査から名勝として指定された「展望地点」では展望 のための施設が約 8 割の場所で整備されており, その他にも様々 な利用のための施設があることがわかった。しかし，これらの整 備・管理は市町村の観光関連の部署または民間団体が行なってい る。また，自然公園の指定範囲内に存在するものが $88 \%$ である ことが明らかになった。さらに，文化財としての保存管理計画も 策定されていないところ半数を超えており, 文化財として展望地 点を保護する意義が整備・管理の実態という点からは見ることが できない。だが， 3 件の事例においても状況は異なるものの， 「展望」という行為そのものの継続のために施設整備などが継続 して行なわれている。また，「展望地点」として名勝指定された ことが，開発の抑制や観光地としての整備のきっかけになったこ とが明らかになった。しかし, いずれの事例も展望地点, 展望対 象ともに変化をしており，文化財として保護されたものを目に見 える形で見出すことは難しい。

「展望地点」の保護は, 「展望」という行為そのものが継続す ることにその意味があると考えられる。そのためには, 展望地点 が人々に利用され続けることが大切である。名勝指定は保護のきっ かけを作るためには有効であり, 整備・管理を行い利用者によっ てより良い環境を整えることで，「展望」行為は継続していくも のと考えられる。

近年では景観法など展望地点に関わる様々な制度が成立してい る。現状として, 文化財行政だけでなく様々な法律や様々な担当 部署の連携によって整備・管理されている「展望地点」であるが, 今後は，景観法のような新しい制度も柔軟に活用することによっ て, 文化財保護法の保護管理体制を補完し，「展望地点」におけ る「展望行為」が継続するよう, 保護していく事が望ましいと考 えられる。

\section{引用・参考文献}

1 ）鄭泰烈・斎藤潮・金在浩（2000）：亭における八景式の風景観賞の特 質についてー韓国の慶尚北道をケーススタディとしてー：都市計画別 冊, 学術研究論文発表論文 $35,739-744$

2 ）石田尾博夫・包清博之（2006）：名勝史跡「坊津」にみる「坊津八景 の景観的意義とその保全条件に関する研究：ランドスケープ研究 69 (5), 731-736

3 ）黑田乃生・小野良平（2004）：明治末から昭和初期における史蹟名勝 天然紀念物保存にみる「風景」の位置づけの変遷：ランドスケープ研 究 67(5), 597-600

4 ）渡辺達三・恒川篤史（1984）：名勝の現状に関する考察：造園雑誌 47 (5), $37-42$

5 ) 丸山宏（2003）：『史蹟名勝天然紀念物』の潮流・保存運動への道程： 復刻版 史蹟名勝天然紀念物解説: 不二出版，5-37／黑田乃生・小野 良平（2004）：明治末から昭和初期における史蹟名勝天然紀念物保存 にみる「風景」の位置づけの変遷：ランドスケープ研究 $67(5), 597$ 600

6 ）田村は, 昭和 5 （1930）年の国立公園候補地の調査で鷲羽山に登り, この山の展望地点と多島海景が新たに生まれる国立公園の核心部にな ると自信を持った，との記述が『岡山縣史蹟名勝天然紀念物調査報告』 に見られる。また，脇水は国立公園には日本風景を代表しうる海岸風 景を指定する事を望み，瀬戸内海の優れた展望地点はどのようなもの であるか，を著書『日本風景誌』の中に記している。田村・脇水は国 立公園の指定を行なうために新しい景観を模索し，その中で多島海景 とそれを望む展望地点を見いだして行った

7 ）文化庁担当者へのヒアリング（平成 19 年 12 月 1 日）による。

8 ）安原啓示（2000）：文化財保護法と名勝：月刊文化財 No.438，4-8

9 ）上原敬二（1943）：本邦景勝地之風景：日本風景美論：大日本出版(侏), $\mathrm{p} 426$

10）名勝指定申請書（1930）：下津井熟羽山：史蹟名勝天然記念物指定第 24 の 2 冊 (文化庁所蔵)

11）下津井鷲羽山：国指定文化財等データベース：文化庁 HP : <http:// www.bunka.go.jp/bsys/maindetails.asp>，2009 年 9 月 1 日参照

12）国立公園 瀬戸内海国立公園：環境省自然環境局 HP : < http://www. env.go.jp/park/setonaikai/>, 2007 年 7 月 10 日参照

13）倉敷新聞：平成 2 年 10 月 3 日号

14）倉敷市（1996）：鷲羽山：新修倉敷市史第八巻 自然・風土・民俗： 山陽新聞社, p83

15）熟羽山の自然をまもる会（1982）：五二 瀬戸大橋：児島風土記：倉 敷文化連盟, p359

16）国指定史蹟名勝天然記念物指定台帳」には昭和 6 年 2 月 20 日に「倉 敷市」が管理団体に指定されている事が明記されており，倉敷市の文 化財担当部署の文化財課が実質管理主体という事が出来る。

17）平成 19 年 7 月 27 日実施

18）網走新聞：昭和 53 年 3 月 18 日号

19）北海道庁拓殖部内北海道景勝地委員会（1934）：48 天都山：『北海 道景勝地概要』北海道拓殖部内北海道景勝地協會, $\mathrm{p} 48$

20）天都山：国指定文化財等データベース：文化庁 HP : < http://www. bunka.go.jp/bsys/maindetails.asp>, 2009 年 9 月 1 日参照

21）網走国定公園:北海道庁 HP：<http://www.pref.hokkaido.lg.jp/ks /skn/environ/parks/abashiri.htm >, 平成 21 年 9 月 18 日参照

22）8.観光：財務省北海道財務局 HP : < http://www.mof-hokkaido.go. $\mathrm{jp} / \mathrm{kitami} /$ report $/ 168 /$ Kannkou.pdf $>$ ，平成 19 年 11 月 21 日参照

23）網走市所在の文化財の管理団体である網走市立郷土博物館担当者への ヒアリング（平成 19 年 8 月 7 日）による。

24）京都市教育會（1915）：雙岡：新撰京都名勝誌, p363

25）京都市役所（1928）：雙岡：京都名勝誌，p506

26）文化庁（1941）：雙ヶ岡指定理由等：昭和 16 年 4 月 史蹟名勝天然 記念物指定第 103 冊

27）雙ヶ岡：国指定文化財等データベース：文化庁 HP : <http://www bunka.go.jp/bsys/maindetails.asp>, 2009 年 9 月 1 日参照

28）脚注 21 に同じ

29）京都市文化観光局（1987）：2.歴史と環境：名勝雙ヶ岡環境整備事業 報告書, p3

30）（表－5）観光地別観光客数の推移：観光客・その流れと傾向：岡山 県 $\mathrm{HP}<$ http://www.pref.okayama.jp/file/open/1253518771_90665 1_22636_pdf2.pdf $>, 2009$ 年 9 月 1 日参照 